\title{
ANALISIS KOMPARATIF PERBEDAAN TINGKAT RELIGIUSITAS SISWA DI LEMBAGA PENDIDIKAN PESANTREN, MAN, DAN SMUN
}

\author{
Oleh: Wahyuni Ismail ${ }^{*}$
}

\begin{abstract}
This study aims at comparing religious application level between students learning at Islamic boarding school, Islamic senior high school, and state senior high school. This study, also, analyzes religious application level in terms of gender, and the dominant religious aspect of application. The religious scale was employed to collect data to 225 year-two senior high school students, 110 females and 115 males. The data were analyzed by using a two-way variant. The result indicates that there is a significant difference $(p=0,008)$ in terms of religious application level, where the students of Islamic boarding school are better than those of Islamic senior high school, while the students of Islamic senior high school are better than those of the state senior high school. This study also reveals that female students are better than their male counterparts in terms of religious application $(p=0,000)$. Finally, the study suggests that the religious aspect which students implement dominantly is worship.
\end{abstract}

KEYWORDS: Religiusitas, Pesantren, MAN, dan SMUN

MASA remaja merupakan salah satu periode perkembangan manusia yang paling banyak mengalami perubahan. Perubahan itu meliputi perubahan fisik, intelektual, moral, sosial, emosional dan religiusitas. Menurut Zakiah Daradjat pada masa ini merupakan saat-saat perpindahan dari masa kanak-kanak ke masa dewasa. ${ }^{1}$ Berbagai macam perubahan meliputi semua segi kehidupannya. Adanya keinginan untuk mencari identitas diri, rasa ingin tahu yang tinggi menyebabkan remaja berusaha untuk mencoba sesuatu hal baru. Terjadinya konflik batin antara ajaran agama dan norma masyarakat dengan keinginan yang tertanam dalam diri remaja sehingga secara psikologis menimbulkan kecemasan dan ketegangan dalam dirinya.

Kondisi psikologis remaja ternyata mempunyai pengaruh yang cukup besar dalam kehidupan beragama mereka. Seperti yang dikemukakan Piaget bahwa remaja memiliki emosi yang sangat labil. ${ }^{2}$ Perkembangan

*Peraih Magister Sains dalam Bidang Psikologi pada Program Pascasarjana UGM Yogyakarta Tahun 2003 ini adalah Dosen Fakultas Tarbiyah dan Keguruan UIN Alauddin Makassar. 
kognitif remaja sudah berfungsi dengan baik sehingga memungkinkan mereka berpikir secara abstrak, kritik, dan teoritik. Remaja akan kritis terhadap hal apapun termasuk mengenai apa yang diyakininya dalam beragama. Thun memberikan suatu wawasan baru bagi pemahaman kehidupan beragama pada masa remaja. Thun tidak memungkiri adanya remaja yang intens terlibat dalam pemantapan kehidupan beragama, tetapi sebagian besar remaja yang diteliti oleh Thun menunjukkan ciri-ciri kehidupan beragama yang masih sama dengan ciri-ciri kehidupan beragama pada masa kanak-kanak, terutama ciri egosentris dan perilaku keagamaan yang ritualistik dan superfisial. Sebagian dari mereka mengalami keraguan dan sebagian yang lain acuh terhadap agamanya. ${ }^{3}$

Melihat kondisi dan kenyataan maka perhatian tertuju pada tujuan pendidikan seperti yang dijelaskan dalam Undang-undang Nomor 20 Tahun 2004 tentang Sistem Pendidikan Nasional dinyatakan bahwa:

Pendidikan Nasional berfungsi mengembangkan kemampun dan membentuk watak serta peradaban bangsa yang bermartabat dalamrangka mencerdsakan kehidupan bangsa, bertujuan untuk berkembangnya potensi peserta didik agar menjadi manusia yang beriman dan bertakwa kepada Tuhan Yang Maha Esa, berakhlak mulia, sehat, berilmu, cakap, kreatif, mandiri, dan menjadi dan menjdi warga Negara yang demokratis serta bertanggung jawab. ${ }^{4}$

Substansi dari tujuan pendidikan tersebut melambangkan pentingnya hakekat pendidikan sebagai usaha membina dan mengembangkan semua potensi siswa yaitu intelektual, keterampilan sosial, dan religiusitas. Berdasarkan hal itu maka lembaga pendidikan sekolah hendaknya mengacu pada usaha pengembangan kelima aspek itu secara seimbang agar terbentuk anak didik cerdas, luwes, dan bersandar pada hati nurani dalam bersikap dan bertindak.

Mengingat hal tersebut maka lembaga pendidikan sekolah sebagai lembaga pendidikan formal hendaknya mengacu pada usaha pengembangan kelima aspek itu secara seimbang agar terbentuk anak didik yang cerdas, luwes, religius dan bersandar pada hati nurani dalam bersikap dan bertindak. Sekarang ini banyak didirikan lembaga pendidikan sekolah. Sekolah sebagai institusi atau lembaga pendidikan formal memegang fungsi dan peranan penting sebagai pelanjut dari proses pendidikan keluarga terutama karena adanya keterbatasan para orang tua mendidik anak-anaknya maka diserahkan ke lembaga pendidikan seiring dengan kepentingan kepribadian dan masa depan anak-anaknya. Terkadang para orang tua sangat selektif dalam menentukan tempat pendidikan untuk menyekolahkan anaknya. Mungkin saja para orang tua yang berasal dari 
keluarga yang taat beragama Islam menyekolahkan anak-anaknya di lembaga pendidikan Islam. Sebaliknya ada para orang tua lebih mengarahkan anak-anak mereka masuk di sekolah umum adapula orang tua merasa kesulitan mengendalikan perilaku anaknya lalu menyekolahkannya di lembaga pendidikan Islam dengan harapan secara kelembagaan sekolah tersebut dapat memberikan pengaruh positif terhadap kepribadian siswa terutama aspek religiusitas.

Berdasarkan fenomena itu perlu dilakukan suatu penelitian khusus tentang tingkat religiusitas siswa yang belajar di pesantren, Madrasah Aliyah Negeri dan Sekolah Menengah Umum Negeri. Perumusan masalah yang menjadi titik fokus dalam penelitian ini adalah apakah ada perbedaan kecerdasan emosional antara siswa yang belajar di Pesantren, Madrasah Aliyah Negeri, dan Sekolah Menengah Umum Negeri? Apakah ada perbedaan religiusitas antara laki-laki dan perempuan yang belajar di Pesantren, Madrasah Aliyah Negeri dan Sekolah Menengah Umum Negeri?

\section{PENGERTIAN RELIGIUSITAS}

Religiusitas berasal dari bahasa Latin religio yang akar katanya adalah religure yang berarti mengikat. ${ }^{5}$ Ini mengandung makna bahwa dalam religi atau agama pada umumnya memiliki aturan-aturan dan kewajiban-kewajiban yang harus dipatuhi dan dilaksanakan oleh pemeluknya dan semua itu berfungsi untuk mengikat seseorang atau sekelompok orang dalam hubungan dengan Tuhan, sesama manusia dan alam sekitarnya. Mangunwijaya membedakan antara istilah religi atau agama dengan religiusitas. Jika religi menunjuk pada aspek-aspek formal yang berkaitan dengan aturan dan kewajiban, maka religiusitas menunjuk pada aspek religi yang telah dihayati oleh seseorang dalam hati. ${ }^{6}$ Pendapat tersebut senada dengan Dister yang mengartikan religiusitas sebagai keberagamaan karena adanya internalisasi agama tersebut ke dalam diri seseorang. ${ }^{7}$

Dari berbagai pendapat di atas dapat ditarik kesimpulan bahwa religiusitas menunjuk pada tingkat keterikatan individu terhadap agamanya. Hal ini menunjukkan bahwa individu telah menghayati dan menginternalisasikan ajaran agamanya sehingga berpengaruh dalam segala tindakan dan pandangan hidupnya.

\section{DIMENSI-DIMENSI RELIGIUSITAS}

Agama merupakan suatu sistem yang terdiri dari beberapa aspek. Zakiah Daradjat mengemukakan bahwa agama meliputi kesadaran beragama dan pengalaman beragama. ${ }^{8}$ Kesadaran beragama adalah aspek 
yang terasa dalam pikiran yang merupakan aspek mental dari aktivitas beragama, sedangkan pengalaman beragama adalah perasaan yang membawa kepada keyakinan yang dihasilkan oleh tindakan. Hurlock mengatakan bahwa religi terdiri dari dua unsur yaitu unsur keyakinan terhadap ajaran agama dan unsur pelaksanaan ajaran agama itu. ${ }^{9}$ Spilka mengatakan bahwa agama meliputi adanya keyakinan, adat, tradisi, dan juga pengalaman-pengalaman individual. ${ }^{10}$ Pembagian dimensi-dimensi religiusitas menurut Glock \& Stark terdiri dari lima dimensi, yaitu:

- Dimensi keyakinan (the ideological dimension), tingkatan sejauh mana seseorang menerima dan mengakui hal-hal yang dogmatik dalam agamanya. Misalnya keyakinan adanya sifat-sifat Tuhan, adanya malaikat, surga, para Nabi, dan sebagainya.

- Dimensi peribadatan atau praktek agama (the ritualistic dimension) yaitu tingkatan sejauh mana seseorang menunaikan kewajiban-kewajiban ritual dalam agamanya. Misalnya menunaikan shalat, zakat, puasa, haji, dan sebagainya.

- Dimensi feeling atau penghayatan (the experiencal dimension) yaitu perasaan keagamaan yang pernah dialami dan dirasakan seperti merasa dekat dengan Tuhan, tentram saat berdoa, tersentuh mendengar ayat kitab suci, merasa takut berbuat dosa, merasa senang doanya dikabulkan dan sebagainya.

- Dimensi pengetahuan agama (the intellectual dimension) yaitu seberapa jauh seseorang mengetahui dan memahami ajaran-ajaran agamanya terutama yang ada dalam kitab suci, hadits, pengetahuan tentang fiqh dan sebagainya.

- Dimensi effect atau pengamalan (the consequential dimension) yaitu sejauhmana implikasi ajaran agama mempengaruhi perilaku seseorang dalam kehidupan sosial. Misalnya mendermakan harta untuk keagamaan dan sosial, menjenguk orang sakit, mempererat silaturahmi, dan sebagainya. ${ }^{11}$

Pendapat itu sesuai dengan lima aspek dalam pelaksanaan ajaran agama Islam tentang aspek-aspek religiusitas yaitu aspek Iman sejajar dengan religious belief; aspek Islam sejajar dengan religious practice; aspek Ihsan sejajar dengan religious feeling; aspek Ilmu sejajar dengan religious knowledge; dan aspek Amal sejajar dengan religious effect. ${ }^{12}$ Dimensi-dimensi tersebut juga sesuai dengan hasil penelitian Kementrian Negara Kependudukan dan Lingkungan Hidup, yaitu a) aspek Iman (religious belief) yang terkait keyakinan kepada Allah, Malaikat, Nabi, dan sebagainya; b) aspek Islam (religious practice), terkait dengan frekuensi atau intensitas pelaksanaan ajaran agama seperti, salat, puasa; c) aspek ihsan (religius feeling), 
berhubungan dengan perasaan dan pengalaman seseorang tentang keberadaan Tuhan, takut melanggar larangnyan-Nya dan sebagai-nya; d) aspek ilmu (religious knowledge) yaitu pengetahuan seseorang tentang ajaran agamanya; dan e) aspek amal (religious effect) terkait tentang bagaimana perilaku seseorang dalam kehidupan bermasyarakat dan sebagainya. ${ }^{13}$ Dapat dikatakan bahwa seseorang dikatakan religius jika orang mampu melaksanakan dimensi-dimensi religiusitas tersebut dalam perilaku dan kehidupannya.

Religiusitas merupakan suatu hal yang sangat esensial bagi kehidupan manusia. Religiusitas dalam Islam menurut Al-Khalifah adalah konsep multi dimensi yang meliputi keimanan atau kepercayaan dan perilaku yang didasarkan pada pikiran dan perbuatan seseorang. Kepercayaan atau keimanan merupakan langkah pertama dalam menumbuhkan perubahan pada kepribadian. Aspek pengalaman keagamaan melibatkan unsur perasaan, emosi, intuisi dan pandangan dalam beragama. Aspek pengalaman keagamaan adalah dimensi yang menyertai keyakinan, pengalaman, dan peribadatan. Perasaan-perasaan atau pengalaman keagamaan yang selalu muncul dalam diri seseorang menyebabkan adanya kontrol terhadap internal dalam dirinya sehingga dapat mencegah terjadinya perilakuperilaku menyimpang yang dapat merugikan diri sendiri atau orang lain. ${ }^{14}$ Dinamika psikologis tentang kematangan interpersonal menurut Nashori dapat dijelaskan bahwa orang yang memiliki kematangan beragama akan menjadikan dirinya pada orang lain dikarenakan setiap agama membawa misi untuk menghadirkan kesejahteraan bagi umat manusia. Dengan kesadaran moral yang tinggi ini, mereka akan memiliki ketergantungan interpersonal. ${ }^{15}$ Uraian di atas dapat disimpulkan bahwa Islam merupakan agama yang universal dengan cakupan dimensi ajaran, yang tidak hanya pada antara diri manusia dengan Tuhan, melainkan juga antara manusia yang diatur dalam ajaran Islam. Dalam ajaran Islam tidak ada diskriminasi antara sesama manusia apapun jenis latar belakangnya baik perbedaan etnis kultur, bahkan sampai perbedaan agama. Sekolah merupakan lingkungan pendidikan kedua sebagai tempat siswa untuk berlatih dan mengembangkan kepribadiannya setelah lingkungan keluarga sebagai lingkungan pendidikan pertama. Sekolah tidak hanya berfungsi sebagai media untuk mentransfer ilmu pengetahuan semata akan tetapi juga sebagai ajang atau tempat pendidikan budi pekerti luhur siswa sehingga pada akhirnya kepribadian siswa dapat dikembangkan sebagaimana yang diharapkan. Ketika orang tua telah menyekolahkan anaknya pada lembaga pendidikan tertentu berarti orang tua telah membagi tugas pendidikan tersebut kepada orang lain. Oleh karena itu, pendidikan keagamaan yang 
diberikan kepada anak pada lembaga pendidikan manapun seperti di pesantren, madrasah atau sekolah umum lainnya sedikit banyak akan memberikan pengaruh pembentukan religiusitas pada siswa.

\section{METODE PENELITIAN}

Variabel yang digunakan dalam penelitian ini dapat dijelaskan sebagai berikut:

- Variabel bebas yaitu lembaga pendidikan yang terdiri dari Pesantren, Madrasah Aliyah Negeri atau MAN, dan Sekolah Menengah Umum Negeri atau SMUN.

- Variabel terikat yaitu religiusitas.

- Variabel moderator yaitu jenis kelamin.

Lembaga Pendidikan adalah pendidikan menengah yang menjadi tempat belajar para siswa, yang terdiri dari: pesantren, yaitu suatu bentuk lembaga pendidikan sistem pondok, dimana proses pendidikan berlangsung secara terus-menerus dengan pengetahuan agama yang lebih dominan daripada pengetahuan umum dan tidak terpaku pada formalitas kelas atau sistem klasikal. Madrasah Aliyah Negeri adalah suatu bentuk lembaga pendidikan yang berciri khas Islam yang terpaku pada formalitas kelas, dengan pelajaran agama sekurang-kurangnya 30\% dari pengetahuan umum. Sekolah Menengah Umum Negeri adalah suatu bentuk lembaga pendidikan Umum dengan kurikulum ilmu pengetahuan umum yang lebih dominan dibandingkan dengan pengetahuan agama, dan terpaku pada formalitas kelas.

Religiusitas dalam penelitian ini adalah menunjuk pada kadar keterikatan siswa terhadap ajaran agamanya. Hal ini menunjukkan bahwa siswa atau santri tersebut telah menginternalisasikan dan menghayati ajaran agamanya sehingga berpengaruh pada perilaku dan pandangan hidupnya. Tingkat religiusitas diukur dengan menggunakan angket yang disusun oleh Afiatin dengan beberapa modifikasi. ${ }^{16}$ Adapun indikator religiusitas ini terdiri dari a) dimensi keyakinan atau ideological involvement, b) dimensi peribadatan atau ritual involvement, c) dimensi penghayatan atau experiencal involvement, d) dimensi pengetahuan agama atau intellectual involvement, e) dimensi pengamalan atau consequential involvement.

Pengambilan data dilakukan berdasarkan teori yang dikemukakan oleh Glock dan Strak. ${ }^{17}$ Sampel merupakan bagian atau representasi dari populasi yang akan diteliti. ${ }^{18}$ Karena dalam penelitian ini sampelnya merupakan siswa-siswa yang tersedia dalam unit populasi, maka teknik pengambilan sampelnya ditetapkan secara purpossive random sampling yaitu memilih sampel berdasarkan tingkat kelas tertentu kemudian setiap siswa 
atau santri dalam kelas dipilih secara acak. Subjek yang menjadi sampel dalam penelitian adalah siswa atau santri yang memiliki ciri-ciri a) berstatus sebagai salah satu santri atau siswa di Pesantren Modern IMMIM, MAN 2 (Model) dan SMUN 2 Makassar, b) duduk di kelas 2, c) berusia antara 16-18 tahun, dalam hal ini usia bukan batasan mutlak karena mungkin ada subyek yang umurnya 14-15 tahun dan duduk di kelas dua sehingga berpeluang juga dijadikan sampel, d) beragama Islam.

Penentuan jumlah sampel dilakukan dengan cara pertama-tama mengambil sampel penelitian di Pesantren dengan alasan karena biasanya jumlah santri yang ada terbatas sampai akhirnya diperoleh data bahwa jumlah santri yang ada sebanyak 36 santri perempuan dan 40 santri lakilaki. Berdasarkan data di Pesantren tersebut maka pengambilan jumlah sampel penelitian di Madrasah Aliyah Negeri 2 diambil sebanyak 37 siswa untuk laki-laki dan 37 siswa untuk perempuan. Hal yang sama juga dilakukan di Sekolah Menengah Umum Negeri 2 dengan jumlah sampel penelitian sebanyak 38 siswa laki-laki dan 37 siswa perempuan.

\section{PENGUJIAN HIPOTESIS PERTAMA}

Uji hipotesis dilakukan melalui Analisis Variansi 1 jalur, hasilnya lihat tabel:

\begin{tabular}{|c|c|c|c|}
\hline Lembaga Pendidikan & Mean Difference & F & Sig \\
\hline S M U N & 74,242 & 0,688 & 0,409 \\
\hline M A N & 684,122 & 3,803 & 0,055 \\
\hline PESANTREN & 961,875 & 7,506 & 0,008 \\
\hline
\end{tabular}

Tabel menunjukkan bahwa ternyata tampak perbedaan yang signifikan tingkat religiusitas siswa yang belajar di lembaga pedidikan SMUN, MAN, dan Pesantren. Tingkat religiusitas yang tertinggi terdapat pada siswa yang belajar di Pesanten dengan nilai perbedaan 961,875. Religiusitas tingkat menengah adalah siswa yang belajar di MAN dengan nilai perbedaan 684,122 . Tingkat religiusitas terendah terdapat pada siswa yang belajar di SMUN dengan nilai perbedaan 74,242.

\section{PENGUJIAN HIPOTESIS KEDUA}

Pengujian hipotesis dilakukan dengan T-Test, dapat dilihat pada tabel di bawah ini: 


\begin{tabular}{|c|c|c|c|}
\hline Jenis Kelamin & M e a $\mathrm{n}$ & $\mathrm{T}$ & Sig \\
\hline Laki-laki & 168,250 & 141,653 & 0,000 \\
\hline Perempuan & 172,816 & 151,064 & 0,000 \\
\hline
\end{tabular}

Tabel menggambarkan bahwa ditemukan perbedaan yang signifikan antara laki-laki dan perempuan dengan nilai perbedaan 172,816 untuk jenis kelamin perempuan dan 168,250 untuk jenis kelamin laki-laki. Perempuan memiliki tingkat religiusitas yang tinggi daripada laki-laki.

\section{ANALISIS TAMBAHAN}

Pengertian analisis tambahan yang dimaksudkan adalah dimensi apakah yang dominan dari variabel religiusitas berdasarkan rerata perbandingannya pada Pesantren, Madarsah Aliyah Negeri dan Sekolah Menengah Umum Negeri. Pembahasan dimensi yang dominan dapat dilaksanakan berdasarkan ukuran rerata. Kerlinger mengatakan bahwa ukuran rerata merupakan salah satu bentuk bilangan indeks yang hasilnya dapat dibandingkan satu sama lain. ${ }^{19}$ Perbandingan dapat dilihat pada tabel berikut

\begin{tabular}{|l|c|c|c|}
\hline \multirow{2}{*}{$\begin{array}{c}\text { Dimensi-dimensi } \\
\text { Religiusitas }\end{array}$} & \multicolumn{3}{|c|}{ Lembaga Pendidikan } \\
\cline { 2 - 4 } & Pesantren & MAN & SMUN \\
\hline Dimensi Keyakinan & 39,00 & 38,00 & 37,00 \\
\hline Dimensi Peribadatan & 39,00 & 39,00 & 37,00 \\
\hline Dimensi Pengamalan & 47,00 & 46,00 & 46,00 \\
\hline Dimensi Perasaan & 40,18 & 38,58 & 38,64 \\
\hline Dimensi Pengetahuan & 10,00 & 9,6 & 6,9 \\
\hline T o t a 1 & $\mathbf{1 7 5 , 1 8}$ & $\mathbf{1 7 1 , 1 8}$ & $\mathbf{1 6 5 , 5 4}$ \\
\hline
\end{tabular}

Berdasarkan tabel dapat diketahui bahwa pada umumnya siswa yang belajar di Pesantren mempunyai tingkat religiusitas yang lebih tinggi daripada siswa yang belajar di Madrasah Aliyah Negeri dan Sekolah Menengah Umum Negeri dengan rerata perbandingan yang relatif rendah. Lebih rinci tabel tersebut menunjukkan bahwa tingkat religiusitas siswa secara keseluruhan didominasi oleh dimensi pengamalan.

\section{PEMBAHASAN HASIL PENELITIAN}

Semua hipotesis yang diajukan ternyata terbukti kebenarannya. Berdasarkan analisis data yang dilakukan ditemukan adanya perbedaan religiusitas antara siswa yang belajar di Pesantren, Madrasah Aliyah 
Negeri, dan Sekolah Menengah Umum serta ditemukannya perbedaan religiusitas antara laki-laki dan perempuan yang belajar di Pesantren, Madrasah Aliyah Negeri, dan Sekolah Menengah Umum Negeri.

\section{Pembahasan Hipotesis Pertama}

Hipotesis pertama diterima karena hal itu sangat memungkinkan terjadi. Sebab sesuai dengan tujuan kurikulum sekolah yang ingin dicapai yaitu melahirkan peserta didik yang tidak hanya cerdas dalam bidang intelektual akan tetapi juga cerdas dalam keagamaan. Lembaga pendidikan Islam memiliki tugas pokok sebagai media yang kuat untuk proses internalisasi nilai-nilai ajaran agama Islam sehingga menuntun para siswa atau santrinya ke arah peningkatan religiusitas. Sesuai dengan hal tersebut, Glock dan Strak mengatakan bahwa pada dasarnya keberagamaan seseorang lebih menunjuk kepada proses internalisasi nilai-nilai agama yang kemudian menyatu dalam diri individu membentuk pola perilaku seharihari. ${ }^{20}$

Kurikulum yang diberlakukan pada lembaga pendidikan umum dalam hal ini Sekolah Menengah Umum Negeri hanya memperhatikan dimensi pengetahuan saja yang memperoleh mata pelajaran keagamaan sekitar dua jam perminggu. Kondisi semacam itu sangat memberikan peluang kepada siswa mengenai rendahnya tingkat religiusitasnya, dengan kata lain adanya perbedaan tingkat religiusitas siswa yang belajar di Sekolah Umum Negeri karena secara kelembagaan minimnya kurikulum keagamaan dan kurangnya interval pertemuan mempelajari bidang studi pendidikan agama Islam. Keadaan sebaliknya terjadi pada kedua lembaga pendidikan Islam yaitu pesantren dan Madrasah Aliyah Negeri dengan kurikulum yang kompleks. Seperti yang dikemukakan Nawawi bahwa Pesantren dan Madrasah di samping mempelajari pengetahuan umum juga mempelajari bidang keagamaan yang lebih banyak. ${ }^{21}$ Alokasi pemberian pendidikan keagamaan dibandingkan pelajaran umum adalah $30 \%: 70 \% .22$ Hal itu sangat memungkinkan timbulnya perbedaan religiusitas pada ketiga lembaga pendidikan itu.

Kondisi tersebut sejalan dengan pendapat Hastjarjo yang mengatakan bahwa salah satu faktor yang menjadikan suatu stimulus itu efektif atau tidak adalah intensitas stimulus yang berarti sehingga jika diberikan stimulus secara intensif maka respons juga semakin kuat. ${ }^{23}$ Pengertian stimulus yang dimaksudkan adalah pelajaran pendidikan agama Islam lebih intens diberikan pada lembaga pendidikan Islam daripada lembaga pendidikan Umum. Hasil penelitian ini sesuai dengan hasil penelitian sebelumnya yang dilakukan oleh Basori menyebutkan bahwa anak yang 
belajar di pesantren memiliki tingkat religiusitas yang tinggi dibandingkan anak yang belajar di sekolah Taman Pendidikan al-Qur'an dan Sekolah Dasar. $^{24}$

Proses pendidikan di pesantren berlangsung terus menerus selama 24 jam sehari di mana kiai, guru, dan santri tinggal bersama dalam suatu lingkungan tertentu. Kondisi tersebut memungkinkan terjadinya interaksi dan komunikasi yang intensif antara sesama penghuni pesantren karena interaksi di pesantren tidak hanya terjadi pada proses belajar mengajar di kelas akan tetapi juga terjadi diluar kelas yang menyentuh aspek-apek psikologis anak sesungguhnya, sehingga akan menambah pemahaman dan pengetahuan kiai atau guru tentang perkembangan dan dinamika proses religiusitas, sosial, emosi, dan intelektual para santri. Interaksi seperti itu menurut Goleman memungkinkan terjadinya perpindahan suasana hati dan pertukaran emosi antara sesama penghuni pesantren. ${ }^{25}$ Kadar hubungan emosi tercermin dari kedekatan sesama penghuni pesantren yang dapat membentuk interaksi yang harmonis antara kiai, guru, dan santri. Kedekatan sesama penghuni pesantren dapat membentuk interaksi. Interaksi tersebut mencerminkan seberapa jauh hubungan yang dirasakan. Semakin erat interaksi, semakin besar pula perasaan bersahabat, bahagia, minat, perhatian dan keterbukaan. Perbedaan yang lain dengan Madrasah Aliyah Negeri dan Sekolah Menengah Umum Negeri adalah kedudukan guru. Keberadaan kiai atau guru di pesantren tidak hanya berfungsi sebagai pengajar dan media transfer ilmu pengetahuan yang dimilikinya, tetapi juga menjadi teladan yang dipedomani dan figur bagi santri dalam kehidupan sehari-hari. Sikap dan perilaku para kiai dan guru mereka di pesantren menjadi suatu ajaran dan pesan yang lebih menyentuh aspek religiusitas santri.

Hal lain yang menyebabkan tingginya tingkat religiusitas di Pesantren adalah adanya proses tafaqqahu $f i$ al-din atau learning by doing yaitu suatu proses pembelajaran dimana setelah pemberian materi atau teori diberikan kemudian sebisa mungkin langsung diaplikasikasikan dalam bentuk perilaku sehari-hari. Berbeda dengan lembaga pendidikan lain seperti Madrasah Aliyah dan Sekolah Umum, interaksi yang terjadi antara siswa dengan pimpinan sekolah, guru, sesama siswa lainnya hanya terjadi pada tataran pembelajaran di kelas dan lingkungan sekolah sehingga kurang menyentuh aspek-apek psikologis anak yang sesungguhnya.

Mengapa hal di atas bisa terjadi? Hal tersebut dimungkinkan terjadi karena pergaulan dan interaksi siswa yang terjadi di Madrasah Aliyah dan Sekolah Menengah Umum, meskipun intensitas pertemuannya hanya terjadi pada lingkungan sekolah, tetapi religiusitas siswa dapat juga 
dipengaruhi oleh faktor lain seperti lingkungan keluarga dan lingkungan sosial kemasyarakatannya. Sebab, pada dasarnya manusia lahir membawa fitrah keagamaan, tetapi dalam perkembangan selanjutnya dipengaruhi oleh pengalaman keagamaan, struktur kepribadian, dan unsur kejiwaan lainnya.26 Para neurolog (ahli syaraf) mengatakan bahwa memang ada mesin syaraf dalam lobus temporal yang dirancang untuk berhubungan dengan agama. ${ }^{27}$ Jalaluddin mengatakan bahwa perkembangan jiwa keagamaan seseorang terbentuk oleh dua faktor, yaitu: pertama, faktor interen meliputi faktor hereditas, usia, kepribadian dan kondisi kejiwaan; dan kedua, faktor eksteren di antaranya faktor lingkungan keluarga, lingkungan masyarakat, dan lingkungan sekolah. ${ }^{28}$

Lingkungan keluarga sangat berperan terhadap perkembangan religiusitas siswa seperti hasil penelitian yang ditemukan oleh Yanta bahwa ada pengaruh konsistensi orang tua dalam mengamalkan nilai-nilai ajaran agama dengan tingkat religiusitas remaja. ${ }^{29}$ Semakin konsisten orang tuanya, maka semakin baik tingkat religiusitas remaja. Dengan begitu, proses internalisai seharusnya dilaksanakan sejak dini. Bahkan, Zakiah Daradjat menyarankan agar proses agama harus sudah dilaksanakan sejak anak masih dalam kandungan. ${ }^{30}$ Afiatin menambahkan bahwa yang paling dominan berperan adalah orang tua. ${ }^{31}$ Pengaruh teman, lingkungan sekolah, lingkungan sosial, dan media massa merupakan faktor penunjang. Faktor yang terpenting adalah faktor interen dari siswa itu sendiri seperti motivasi untuk meningkatkan keimanan, peribadatan, pengamalan dan pengetahuan beragama dalam kehidupannya. Seringnya stimulus tentang keagamaan yang terjadi di lembaga pendidikan pesantren itulah yang memberikan peluang besar kepada siswa dalam meningkatkan religiusitas mereka.

\section{Pembahasan Hipotesis Kedua}

Hasil analisis data menunjukkan bahwa hipotesis kedua yang menyebutkan ada perbedaan religiusitas antara laki-laki dan perempuan yang belajar di Pesantren, Madrasah Aliyah Negeri, dan Sekolah Menengah Umum Negeri terbukti kebenarannya.

Berdasarkan fenomena yang ditemukan di lapangan bahwa pada umumnya lembaga pendidikan Sekolah Menengah Umum yang ada di Makassar terdapat kegiatan ekstrakurikuler yaitu dengan membentuk suatu ikatan pelajar muslim dan kegiatan keagamaan lainnya seperti pengajian rutin dengan durasi pertemuan 1-2 kali seminggu serta adanya prasarana yang disediakan oleh pihak sekolah yaitu musala sebagai tempat pertemuan. Berangkat dari kondisi tersebut maka dapat diketahui bahwa 
meskipun dalam kurikulum Sekolah Menengah Umum siswa hanya mendapatkan jumlah pelajaran agama rata-rata dua jam dalam seminggu, tetapi para siswa tetap belajar dan mendapatkan pengetahuan keagamaan dari kegiatan ekstrakurikuler tersebut. Walaupun lembaga pendidikan Islam dalam hal ini Pesantren dan Madrasah Aliyah Negeri memiliki tugas pokok sebagai media internalisasi nilai-nilai agama Islam bagi siswa atau santrinya, lembaga pendidikan umum juga berbenah diri dengan menyiapkan semacam kegiatan ekstrakurikuler tersebut sehingga siswa dapat berperan aktif menginternalisasikan ajaran agama yang didapatkan dalam kehidupannya.Artinya, siswa dan siswi Sekolah Menengah Umum Negeri memperoleh penambahan pengetahuan, pengalaman, dan penghayatan religius di luar jam pelajaran sekolah.

Mengenai pengaruh faktor jenis kelamin terhadap religiusitas, tampaknya penelitian yang telah ada sering menunjukkan hasil yang tidak konsisten. Sebagian penelitian menemukan adanya perbedaan religiusitas antara laki-laki dan perempuan dan sebagian penelitian tidak menunjukkan adanya perbedaan jenis kelamin. Perbedaan jenis kelamin antara lakilaki dan perempuan juga menimbulkan perbedaan dalam berperilaku. Perbedaan religiusitas laki-laki dan perempuan dibuktikan oleh Ficher terhadap subyek yang beragama Katolik antara lain bahwa keterlibatan dalam ritual perempuan ternyata lebih tinggi daripada laki-laki. ${ }^{32}$ Miller \& Hoffman menemukan bahwa laki-laki lebih cenderung memilih resiko dan perempuan cenderung menghindari resiko yang berhubungan dengan religiusitas. ${ }^{33}$ Hal senada dikemukakan Suziedalis \& Potrin dalam penelitian mereka tentang bahwa religiusitas berhubungan dengan self image, remaja perempuan berkaitan dengan dunia luar seperti mencari pertolongan dan kemampuan sosial dan remaja laki-laki berhubungan dengan aktivitas yang ambisius. ${ }^{34}$

Hasil penelitian ini tampaknya tidak sejalan dengan hasil penelitian yang dilakukan oleh Adisubroto, ${ }^{35}$ Basori ${ }^{36}$ yang tidak menemukan adanya perbedaan religiusitas antara laki-laki dan perempuan yang belajar di Pesantren, Taman Pendidikan al-Qur'an dan Sekolah Dasar. Afiatin juga tidak menemukan perbedaan religiusitas antara laki-laki dan perempuan pada SMP dan SMU Negeri dan Swasta. ${ }^{37}$ Hasil penelitian Andriyani tidak menunjukkan adanya perbedaan religiusitas yang signifikan antara lakilaki dan perempuan yang menempuh pendidikan di Pesantren dan Madrasah Aliyah Negeri. ${ }^{38}$ Hipotesis penelitian ini terbukti kemungkinan disebabkan oleh adanya karakteristik yang berbeda maupun lokasi penelitian yang tidak sama, atau disebabkan juga oleh proses internalisasi pemahaman religiusitas yang dimiliki perempuan lebih mendalam dan 
komprehensif dibandingkan dengan pemahaman yang dimiliki laki-laki. Kemungkinan lain karena adanya perubahan dan perkembangan yang terjadi dan selalu mewarnai kehidupan keseharian lembaga pendidikan yang memberikan peluang yang sama kepada siswa atau santri untuk berkembang lebih maju dibandingkan dengan masa-masa sebelumnya. Perkembangan infomasi turut memacu dan menentukan kepribadian siswa atau santri termasuk religiusitasnya, sehingga perbedaan cara mengekspresikan dan mengamalkan ajaran agama antara laki-laki dan perempuan tidak lagi menjadi kendala dalam mengembangkan pola-pola interaksi yang berlaku di setiap lembaga pendidikan itu.

\section{PENUTUP}

Berdasarkan hasil penelitian dapat disimpulkan bahwa hal-hal sebagai berikut:

1. Ditemukan perbedaan signifikan tingkat religiusitas siswa yang belajar di Pesantren, Madrasah Aliyah Negeri, dan Sekolah Menengah Umum Negeri. Siswa yang belajar di lembaga pendidikan Pesantren memiliki tingkat religiusitas yang tinggi dibandingkan siswa yang belajar di Madrasah Aliyah Negeri dan Sekolah Menengah Umum Negeri.

2. Terdapat perbedaan yang signifikan tingkat religiusitas antara laki-laki dan perempuan. Perempuan memiliki tingkat religiusitas yang tinggi dibandingkan dengan laki-laki yang belajar di lembaga pendidikan Pesantren, Madrasah Aliyah Negeri, dan Sekolah Menengah Umum Negeri.

3. Tingkat religiusitas siswa yang belajar di Pesantren, Madrasah Aliyah Negeri, dan Sekolah Menengah Umum Negeri didominasi oleh dimensi pengamalan.

\section{CATATAN AKHIR:}

1. Zakiah Daradjat, Ilmu Jiwa Agama, Jakarta: Bulan Bintang, 1993, h. 69.

2. E-Psikologi. Com, Remaja dan Agama, http://www.yahoo.com, 2000, h. 5.

3. Dister Wullf N., Psychology of Religion: Classic and Contemporary View, New York: Willy, 1991, h. 83.

4. Undang-undang RI Nomor 20 Tahun 2003 tentang Sisdiknas Beserta Penjelasannya, Bandung: Bulan Bintang, 2003, h. 7.

5. Driyarkara, N., Percikan Filsafat, Jakarta: PT Pembangunan, 1978.

6. Mangunwijaya, Y.B., Sastra dan Religiusitas, Jakarta, Sinar Harapan, 1982.

7. Subandi, "Hubungan antara Tingkat Religiusitas dengan Kecemasan pada Remaja", Laporan Penelitian, Yogyakarta: Fakultas Psikologi UGM, 1988, h.5.

8. Zakiah Daradjat, Ilmu Jiwa Agama, Jakarta, Bulan Bintang, 1993, h. 34. 
9. Elizabeth B. Hurlock, Adolescent Development, Tokyo: McGraw-Hill Kogakusha, Ltd, 1973, h. 217.

10. Spilka, B., Hood, R.W., Gorsuch, RL., The Psychology of Religion: An Empirical Approach, New Jersey: Engelwood Cliff, Prentice Hall, 1985, h.107.

11. Robinson, J.P. and Shaver, R.R., Measures of Socially Psychologycal Attitude: The Problem of Maladaptive Behavior, 7th Ed. New Jersey: Prentice Hall, 1973, h. 23.

12. Subandi, "Hubungan antara Tingkat Relgiusitas dengan Kecemasan pada Remaja", Laporan Penelitian, 1988, h. 21.

13. Kementrian Negara Kependudukan dan Lingkungan Hidup, "Studi Kualitas Non-Fisik Manusia Indonesia", Laporan Penelitian Pendahuluan, Jakarta, 1987.

14. Al-Khalifah, "Religiosity in Islam as A Protective Mechanism Againt Criminal Tempation", The American Journal of Islamic Social Sciences, 11. 1, 1-12, 1994.

15. Fuad Nashori, "Manusia Sebagai Homoreligius", Psikologika, N. 3, 1997, h. 3-5.

16. Afiatin, "Religiusitas Remaja: Studi tentang Kehidupan Beragama Remaja di Daerah Istimewa Yogyakarta", Laporan penelitian, Yogyakarta: Fak. Psikologi UGM, 1997, h. 13-15.

17. Robinson, J.P. and Shaver, R.R., Measures of Socially Psychologycal Attitude: The Problem of Maladaptive Behavior.

18. Sutrisno Hadi., Statistik Jilid 2, Yogyakarta, Andi Offset, 2000, h. 57.

19. Kerlinger, F.N., Asas-Asas Penelitian Behavior, terjemahan Simatupang, Yogyakarta: Gadjah Mada University, 1999, h. 74.

20. Robertson, R., Agama dalam analisis dan Interpretasi Sosiologis, Jakarta: Rajawali Press, 1992.

21. Hadang Nawawi., Pendidikan dalam Islam, Surabaya: Al-Ikhlas, 1993, h. 40.

22. Departemen Agama Republik Indonesia, Kurikulum Madrasah Aliyah Negeri, Jakarta: 1994, h. 36.

23. Hastjarjo, T.D., Seri Psikologi Belajar. Kondisioning Klasikal. Tidak diterbitkan, 1994, h. 27.

24. Basori, K., "Perbedaan Religiusitas dan Kemandirian antara Anak yang Belajar di Sekolah Dasar, Taman Pendidikan Al-Qur'an, dan Pesantren", Tesis. Yogyakarta: Pascasarjana Universitas Gadjah Mada, 1955, h. 89.

25. Daniel Goleman, Emotional Intellegence, Alih Bahasa, T. Hermaya, Jakarta: Gramedia Pustaka Utama, 2000, h. 64.

26. Jamaluddin dan Ramayulis, Pengantar Ilmu Jiwa Agama, Jakarta: Kalam Mulia, 1993.

27. Danah Zohar and Ian Marshal, SQ: Memanfaatkan Kecerdasan Spritual dalam Berpikir Integralistik dan Holistik untuk Memahami Kehidupan, Terjemahan: Astuti, dkk., Bandung: Mizan, 2000, h. 82.

28. Jalaluddin, Psikologi Agama, Jakarta: PT. Raja Grafindo Persada, 1997, h. 279.

29. Yanta, I.P., Hubungan antara Persepsi terhadap Konsistensi Orang Tua dalam Mengamalkan Nilai-nilai Agama yang Dianutnya dengan Tingkat Religiusitas pada Siswa STM Yogyakarta, Skripsi, Fakultas Psikologi UGM, 1995, h. 95.

30. Daradjat, Ilmu Jiwa Agama. h.32

31. Afiatin, T., "Religiusitas Remaja: Studi tentang Kehidupan Beragama Remaja di Daerah Istimewa Yogyakarta", Laporan Penelitian, h .23.

32. Hallahmi, B. and Argyle, M., The Psychology of Religiuos Behavior, Belief and Experience, London and New York: Rout Ledge, 1997. 
33. Hallahmi, B. and Argyle, M., The Psychology of Religiuos Behavior, Belief and Experience.

34. Hallahmi, B. and Argyle, M., The Psychology of Religiuos Behavior, Belief and Experience.

35. Adisubroto, D., "Sifat Religiusitas pada Suku Bangsa Jawa dan Suku Bangsa Minangkabau", Jurnal Psikologi, Yogaykarta: Fakultas Psikologi UGM, 1992, h. 47.

36. Basori, K., Perbedaan Religiusitas dan Kemandirian antara Anak yang Belajar di Sekolah Dasar, Taman Pendidikan Al-Qur'an, dan Pesantren. Tesis, h. 67

37. Afiatin, T., "Religiusitas Remaja : Studi tentang Kehidupan Beragama Remaja di Daerah Istimewa Yogyakarta". Laporan penelitian.

38. Abdullah, A., "Pendidikan Islam di Indonesia", Jurnal Suhuf, No. 2. Tahun. IV, 1992, h.18-24.

\section{DAFTAR PUSTAKA}

Abdullah, A., Pendidikan Islam di Indonesia, Jurnal Suhuf, No. 2. Tahun. IV, 18-24, 1992.

Adisubroto, D., "Sifat Religiusitas pada Suku Bangsa Jawa dan Suku Bangsa Minangkabau", Jurnal Psikologi, Yogaykarta: Fakultas Psikologi UGM, 1992.

Afiatin, T., "Religiusitas Remaja: Studi tentang Kehidupan Beragama Remaja di Daerah Istimewa Yogyakarta", Laporan penelitian, Yogyakarta: Fak. Psikologi UGM, 1997.

Al-Khalifah, "Religiosity in Islam as A Protective Mechanism Againt Criminal Tempation", The American Journal of Islamic Social Sciences, 11. 1, 1-12, 1994.

Basori, K., "Perbedaan Religiusitas dan Kemandirian antara Anak yang Belajar di Sekolah Dasar, Taman Pendidikan Al-Qur'an, dan Pesantren, Tesis, Yogyakarta: Pascasarjana Universitas Gadjah Mada, 1955.

Daradjat, Z., Kesehatan Mental dalam Keluarga, Jakarta: Pustaka Antara, 1992.

-------, Ilmu Jiwa Agama, Jakarta: Bulan Bintang, 1993.

Departemen Agama Republik Indonesia, 1994. Kurikulum Madrasah Aliyah Negeri. Jakarta, 1994.

Dister, N.S., Pengalaman dan Motivasi Beragama, Yogyakarta: Kanisius, 1988.

Djumhur, H. dan Danasaputra, Sejarah Pendidikan, Bandung: CV Ilmu, 1979.

Driyarkara, N., Percikan Filsafat, Jakarta: PT Pembangunan, 1978.

Ensiklopedia Islam, Jakarta: Internusa, 1999.

E-Psikologi. com., Remaja dan Agama, http:/ / www.Yahoo.com, 2000.

Goleman, D., Emotional Intellegence, terjemahan T. Hermaya, Jakarta: Gramedia Pustaka Utama, 2000.

Hadi, S., Statistik Jilid 2, Yogyakarta: Andi Offset, 2000.

Hall, J.A., Aist, M.B., and Pike,K.M., "Nonverbal Behavior and Person Description in Men's and Women's Prose", Journal of Nonverbal Behavior, 7, 213-222, 1984.

Hallahmi, B. and Argyle, M., The Psychology of Religiuos Behavior, Belief and Experience, London and New York: Rout Ledge, 1997.

Hastjarjo, T.D., Seri Psikologi Belajar: Kondisioning Klasikal, Tidak Diterbitkan, 1994. 
Hawari, D., Al-Qur'an Ilmu Kedokteran Jiwa dan Kesehatan Mental, Jakarta: Dana Bhakti Yasa, 1997.

Hurlock, E.B., Adolescent Development, Tokyo: McGraw-Hill Kogakusha,Ltd, 1973.

Jalaluddin, Psikologi Agama, Jakarta: PT. Raja Grafindo Persada, 1997.

Jamaluddin dan Ramayulis, Pengantar Ilmu Jiwa Agama, Jakarta: Kalam Mulia, 1993.

Kerlinger, F.N., Asas-Asas Penelitian Behavior, terjemahan Simatupang, Yogyakarta: Gadjah Mada University, 1999.

Kementrian Negara Kependudukan dan Lingkungan Hidup, "Studi Kualitas NonFisik Manusia Indonesia", Laporan Penelitian Pendahuluan, Jakarta: 1987.

Madjid, N., Bilik-bilik Pesantren, Jakarta: Paramadina, 1997.

Mangunwijaya, Y.B., Sastra dan Religiusitas, Jakarta: Sinar Harapan, 1982.

Nawawi. H., Pendidikan dalam Islam, Surabaya: Al-Ikhlas, 1993.

Nashori, F., "Manusia Sebagai Homoreligius", Psikologika, N. 3, 3-5, 1997.

Robertson, R., Agama dalam analisis dan Interpretasi Sosiologis, Jakarta: Rajawali Press, 1992.

Robinson, J.P. and Shaver, R.R., Measures of Socially Psychologycal Attitude: The Problem of Maladaptive Behavior, $7^{\text {th }}$ Ed. New Jersey: Prentice Hall, 1973.

Spilka, B., Hood, R.W., Gorsuch, RL., The Psychology of Religion: An Empirical Approach., New Jersey, Engelwood Cliff: Prentice Hall, 1985.

Subandi, Hubungan antara tingkat Relgiusitas dengan Kecemasan Pada Remaja, Laporan Penelitian, Yogyakarta, Fakultas Psikologi UGM, 1988.

Undang-undang RI No. 20 Tahun 2003 tentang Sisdiknas Beserta Penjelasannya, Bandung: Bulan Bintang, 2003.

WWW.ut.ac.id./ol-supt/FKIP/PAB 14422/kurikulum.atm.

Wullf, D.N., Psychology of Religion: Classic and Contemporary View, New York: Willy, 1991.

Zohar, D, and Marshal, I., SQ, Memanfaatkan Kecerdasan Spritual dalam Berfikir Integralistik dan Holistik untuk Memahami Kehidupan, Terjemahan: Astuti, dkk. Bandung, Mizan, 2000. 